\title{
THE FATE OF INTRAVENOUSLY ADMINISTERED CALCIUM. EFFECT ON URINARY CALCIUM AND PHOSPHORUS, FECAL CALCIUM AND CALCIUM-PHOSPHORUS BALANCE ${ }^{1}$
}

\author{
By CURTIS H. BAYLOR, 2,3 HELEN E. VAN ALSTINE,4, 5 E. HENRY KEUTMANN, \\ AND SAMUEL H. BASSETT ${ }^{6}$
}

\begin{abstract}
(From the Department of Medicine, University of Rochester School of Medicine and Dentistry and the Medical Clinics of the Strong Memorial and Rochester Municipal Hospitals)
\end{abstract}

(Submitted for publication January 31, 1950; accepted, June 5, 1950)

The fate of parenteral calcium when given to man in amounts which contribute an appreciable fraction of the total intake has not been extensively investigated. While it is generally agreed that intravenous calcium salts disappear rapidly from the blood stream (1), there have been differences in opinion as to whether the calcium was excreted mainly in the urine, partitioned between urine and feces or retained in the bones and other tissues.

The apparently conflicting results of balance studies may be reconciled to a considerable degree if one considers the manner and quantity in which the supplementary calcium has been given as well as the condition of the recipient. Some experiments pertinent to the present discussion may be cited briefly.

Grosser (2) followed the intake and output of rachitic infants treated with subcutaneous injections of calcium glycerophosphate and calcium chloride. A large part of the injected calcium must have been absorbed and retained since little evidence of increased excretion in urine or feces can be found on perusal of his work. Albright and Sulkowitch (3) gave a patient with idiopathic hypoparathyroidism daily intravenous injections of calcium gluconate equivalent to $550 \mathrm{mg}$. of calcium

1 This study was supported by a grant from the American Cancer Society on recommendation of the Committee on Growth of the National Research Council and the Fluid Research Fund of the University of Rochester.

2 Professor of Medicine (on leave) from the University of Beirut, Lebanon.

3 Present adress: The Texas Company, 135 East 42nd Street, New York 17, New York.

4 Hochstetter Fellow in Medicine.

- Present adress: Vassar College, Poughkeepsie, New York.

- Present address: Veterans Administration Center, Los Angeles 25, California. for six days. The initial very low level of serum calcium rose transiently, but there was no significant increase in the excretion of calcium in the urine or stools. The retention of the parenteral calcium was almost complete.

The question of provoking intestinal excretion of calcium by intravenous calcium has been investigated in six normal subjects by McCance and Widdowson (4). They gave daily injections of the gluconates of calcium and magnesium equivalent to $186 \mathrm{mg}$. Ca and $219 \mathrm{mg}$. Mg for 14 days. A careful balance was conducted during this interval. Most of the supplementary calcium was recovered promptly in the urine and the ratios of fecal calcium to food calcium did not change. In their opinion, the gastro-intestinal tract did not participate actively in the excretion of calcium. It is clear that there was very little retention of the injected calcium; however, the possible effect of the simultaneous administration of magnesium on the excretion of calcium does not seem to have been considered. Duncan, Mirick and Howard (5) found variable but usually small amounts of calcium in the fecal excretions of patients receiving total intravenous alimentation. From their data one gains the impression that the parenteral administration of as much as $330 \mathrm{mg}$. of $\mathrm{Ca}$ per 1.73 square meters of body surface per day had little effect on the amount recoverable in the feces. On the other hand, Armstrong and Lienke (6) on injection of labeled calcium $\left(\mathrm{Ca}^{45}\right)$ in the rat found that from six to ten times as much appeared in the feces as in the urine.

In general, the human studies are confirmatory of the experiments of Nicolaysen (7) on the dog. Subcutaneous injections of calcium gluconate in this animal cause increased excretion of calcium in the urine, but no increase in fecal excretion. 
The difference between the amount injected and excreted in the urine is presumably retained in the bones. Since retention of phosphorus is obligatory in the formation of bone salts, it is to be expected that the retention of parenteral calcium would affect the phosphorus balance. This was found to be the case in Albright's (3) experiment where the urinary excretion of $\mathrm{P}$ decreased markedly and the retention of phosphorus increased.

Numerous gradations must exist between the extremes of complete retention and almost complete excretion of parenterally administered calcium. It is probable also that greater urinary losses will be incurred when calcium salts are given intravenously rather than subcutaneously. Whether the responses encountered can be shown to fall into definite patterns, related to age, growth, disease, etc., will require the amassing of a much larger body of evidence than is available at present. Further confirmation of the findings of earlier investigators is desirable especially with regard to those factors which influence the retention of calcium and its excretion in the urine.

The experiments detailed in subsequent sections of this report were done in the course of other studies so that there is considerable variability in the programs to which patients were subjected. All individuals, however, had been on adequate diets for some time prior to starting the investigation and were continued on them during the study. They were either in nitrogen equilibrium or positive nitrogen balance. In the periods of parenteral calcium administration, each received the same daily dose of 3 per cent calcium gluconate given as nearly as possible at identical hours. There were no untoward reactions. Except in one instance, which may have been due to failure of a patient to cooperate fully, no evidence was adduced to suggest transfer of appreciable amounts of cal-

TABLE I

Daily irtakes

\begin{tabular}{l|c|c|c|c|c|c|c}
\hline \hline Subject & Calories & Protein & Fat & CHO & Ca & P & N \\
\cline { 3 - 7 } & & gm. & $g m$. & $g m$. & $m g$. & $m g$. & gm. \\
M. G. & 2288 & 76 & 104 & 262 & 1111 & 1400 & 12.15 \\
C. R. & 1775 & 112 & 59 & 199 & 1465 & 1688 & 17.88 \\
A. H. & 3520 & 98 & 192 & 350 & 2373 & 2331 & 15.63 \\
\hline
\end{tabular}

Values for $\mathrm{Ca}, \mathrm{P}$, and $\mathrm{N}$ were determined by the analysis of sample diets. Protein $=$ Diet $N \times 6.25$. Fat and carbohydrate have been estimated from tables. cium to feces. Other findings of interest were that 1) the administration of large doses of calcium depressed the urinary excretion of calcium in postcontrol periods; 2) large oral doses of a soluble phosphate decreased the excretion of calcium in the urine; 3) the injection of calcium decreased the excretion of phosphorus in the urine and, 4) calcium gluconate appeared to have a small nitrogen sparing effect in two subjects.

\section{MATERIALS AND METHODS}

Experimental subjects. The three subjects of this study remained continuously on the Metabolism Division during the investigation. Each individual received the same diet from day to day, but the diets differed somewhat from individual to individual. All of the diets were relatively high in calcium. (See Table I) M. G. and C. R. were women aged 37 and 57 , respectively. M. G. was essentially normal, while $C$. R. had severe postmenopausal osteoporosis. In the case of the two women who were in a good state of nutrition, the caloric intake was adjusted to prevent insofar as possible either gain or loss of weight. A. H., on the other hand, a male, presented findings typical of anorexia nervosa and was studied during a phase of repletion in which he was in markedly positive nitrogen balance and gaining in weight.

Analysis of food and excreta. The intakes of calcium, phosphorus and nitrogen were determined by analysis of a series of sample diets prepared in the same manner as the food eaten by the patients. Average values were used. Urine was collected in periods of 24 hours. Nitrogen determinations were done by macro-Kjeldahl. Aliquots of the daily urine were pooled in periods of four, five or six days and the pools paralleled the collection of feces. Calcium and phosphorus of the urine, feces and diet were determined gravimetrically, using the procedure of Washburn and Shear (8). In certain instances, calcium and phosphorus analyses were done daily or even at shorter intervals on urine. At such times calcium was determined by the method of Kochakian and Fox (9), and phosphorus by the procedure of Fiske and Subbarow (10). Calcium gluconate solution was prepared as a sterile 3 per cent solution. One hundred $\mathrm{ml}$. aliquots were injected intravenously twice daily at a rate not in. excess of 80 to 90 drops per minute. If the subject complained of burning or flushing, the flow was decreased until the symptoms disappeared.

\section{RESULTS}

Diet. The analytical data on the diets appear in Table I. It is to be recalled that the values for fat and carbohydrate were obtained from standard dietary tables; those for nitrogen, calcium, and phosphorus are from the analysis of sample diets. Protein in diet $=$ nitrogen $\times 6.25$. Calories are approximate. 
TABLE II

Effect of intravenous calcium on urinary and fecal calcium and calcium balance

\begin{tabular}{|c|c|c|c|c|c|c|c|}
\hline Subject & Period & No. days & Intake & Urine & Stool & Balance & Medication \\
\hline $\begin{array}{l}\text { M. G. } \\
\text { Female } \\
\text { Age } 37\end{array}$ & $\begin{array}{c}5-9 \\
10 \& 11 \\
12\end{array}$ & $\begin{array}{r}25 \\
10 \\
5\end{array}$ & $\begin{array}{c}m g . / d a y \\
1111 \\
1661 \\
1111\end{array}$ & $\begin{array}{l}m g . / \text { day } \\
238 \\
538 \\
147\end{array}$ & $\begin{array}{c}\text { mg./day } \\
841 \\
882 \\
882\end{array}$ & $\begin{array}{l}m g . / \text { day } \\
+32 \\
+221 \\
+82\end{array}$ & $\begin{array}{l}\text { Control } \\
\text { I.V. calcium } 550 \mathrm{mg} \text {./day } \\
\text { Control }\end{array}$ \\
\hline \multirow[t]{3}{*}{ Normal } & $\begin{array}{c}14,16,17 \\
18 \& 19 \\
20\end{array}$ & $\begin{array}{r}15 \\
10 \\
5\end{array}$ & $\begin{array}{l}1111 \\
1661 \\
1111\end{array}$ & $\begin{array}{r}178 \\
519 \\
87\end{array}$ & $\begin{array}{l}806 \\
969 \\
969\end{array}$ & $\begin{array}{l}+127 \\
+173 \\
+45\end{array}$ & $\begin{array}{l}\text { T.P.* } 25 \mathrm{mg} . / \text { day I.M. } \\
\text { I.V. calcium } 550 \mathrm{mg} \cdot / \text { day and T.P. } 25 \\
\text { mg./day I. M. } \\
\text { T.P. } 25 \mathrm{mg} . / \text { day I.M. }\end{array}$ \\
\hline & $21 \& 22$ & 10 & 1111 & 78 & 820 & +213 & Control \\
\hline & $\begin{array}{c}23-26 \\
27 \\
28\end{array}$ & $\begin{array}{r}20 \\
5 \\
5\end{array}$ & $\begin{array}{l}1111 \\
1605 \\
1111\end{array}$ & $\begin{array}{l}112 \\
469 \\
102\end{array}$ & $\begin{array}{l}790 \\
683 \\
683\end{array}$ & $\begin{array}{l}+209 \\
+453 \\
+326\end{array}$ & $\begin{array}{l}\text { Alpha estradiol benzoate } 1.66 \mathrm{mg} \text {. I.M. } \\
\text { every other day } \\
\text { I.V. calcium } 494 \mathrm{mg} . / \mathrm{day} \text { and alpha es- } \\
\text { tradiol benzoate } \\
\text { Alpha estradiol benzoate }\end{array}$ \\
\hline \multirow{3}{*}{$\begin{array}{l}\text { C. R. } \\
\text { Female } \\
\text { Age } 57 \\
\text { Osteoporosis }\end{array}$} & $\begin{array}{c}1-5 \\
6 \& 7 \\
8\end{array}$ & $\begin{array}{r}30 \\
12 \\
6\end{array}$ & $\begin{array}{l}1465 \\
2003 \\
1465\end{array}$ & $\begin{array}{l}229 \\
641 \\
195\end{array}$ & $\begin{array}{l}1350 \\
1250 \\
1250\end{array}$ & $\begin{array}{r}-114 \\
+112 \\
+\quad 20\end{array}$ & $\begin{array}{l}\text { Control } \\
\text { I.V. calcium } 538 \mathrm{mg} \cdot / \text { day } \\
\text { Control }\end{array}$ \\
\hline & $35 \& 36$ & 8 & 2008 & 600 & 1369 & +39 & I.V. calcium $543 \mathrm{mg} . /$ day \\
\hline & $\begin{array}{c}30-33 \\
41 \& 42\end{array}$ & $\begin{array}{r}16 \\
8\end{array}$ & $\begin{array}{l}1465 \\
1999\end{array}$ & $\begin{array}{l}101 \\
452\end{array}$ & $\begin{array}{l}1365 \\
1389\end{array}$ & $\begin{array}{r}-1 \\
+158\end{array}$ & $\begin{array}{l}65 \text { ml. molar solution } \mathrm{NaH}_{2} \mathrm{PO}_{4} \text { daily by } \\
\text { mouth } \\
\text { Phosphate as in periods } 30-33 \text { plus } 534 \mathrm{mg} \text {. } \\
\text { calcium I.V. daily }\end{array}$ \\
\hline $\begin{array}{l}\text { A. H. } \\
\text { Male } \\
\text { Age } 44 \\
\text { Anorexia } \\
\text { nervosa }\end{array}$ & $\begin{array}{c}7-9 \\
11-13\end{array}$ & $\begin{array}{l}12 \\
12\end{array}$ & $\begin{array}{l}2373 \\
2924\end{array}$ & $\begin{array}{l}184 \\
421\end{array}$ & $\begin{array}{l}2375 \\
2295\end{array}$ & $\begin{array}{l}-186 \\
+208\end{array}$ & $\begin{array}{l}\text { Control } \\
\text { I.V. calcium } 551 \mathrm{mg} . / \text { day }\end{array}$ \\
\hline
\end{tabular}

* Refers to intramuscular testosterone propionate.

Effect of intravenous calcium on urinary and fecal calcium and calcium balance. (Table II) M. G., who was an essentially normal woman, received calcium on three separate occasions. The first series of injections were given after an interval of 30 days on the standard diet. A very steady preliminary value for urinary calcium was obtained with an average of $238 \mathrm{mg}$. a day (see also Figure 1) and she was found to be in approximate calcium equilibrium. If one assumes that the same amount of calcium in the urine was attributable to the basal diet during both the pre-gluconate periods and during the course of injection, then only 58 per cent of the intravenous dose was excreted. An interesting phenomenon was observed in the post-gluconate control periods of this patient and it appears also, but to a lesser degree, in the data obtained on C. R. (Table II). In the interval immediately following the administration of calcium, less calcium was excreted in the urine than in the preliminary periods of observa- tion. The persistence of this lower rate of excretion through periods 13 to 17 may have been due to therapy with testosterone propionate. However, when the injections of calcium were repeated while the patient was definitely under the influence of androgen (periods 18 and 19) there was a further decrease in the average daily urinary calcium of the after periods (periods 20 through 22). Since androgen has been found to cause a reduction in the excretion of calcium in the urine $(11,12)$, one must concede that the effect may have been due to testosterone propionate. On the other hand it is equally probable that the two actions were superimposed. There was no evidence that androgen increased the retention of calcium. The effect of estrogen on the excretion of calcium was less certain for there was only one five-day period during which the injections were given. Nevertheless the full action of the alpha estradiol benzoate should have been attained since it had been given for 20 preceding days. After the smaller excre- 

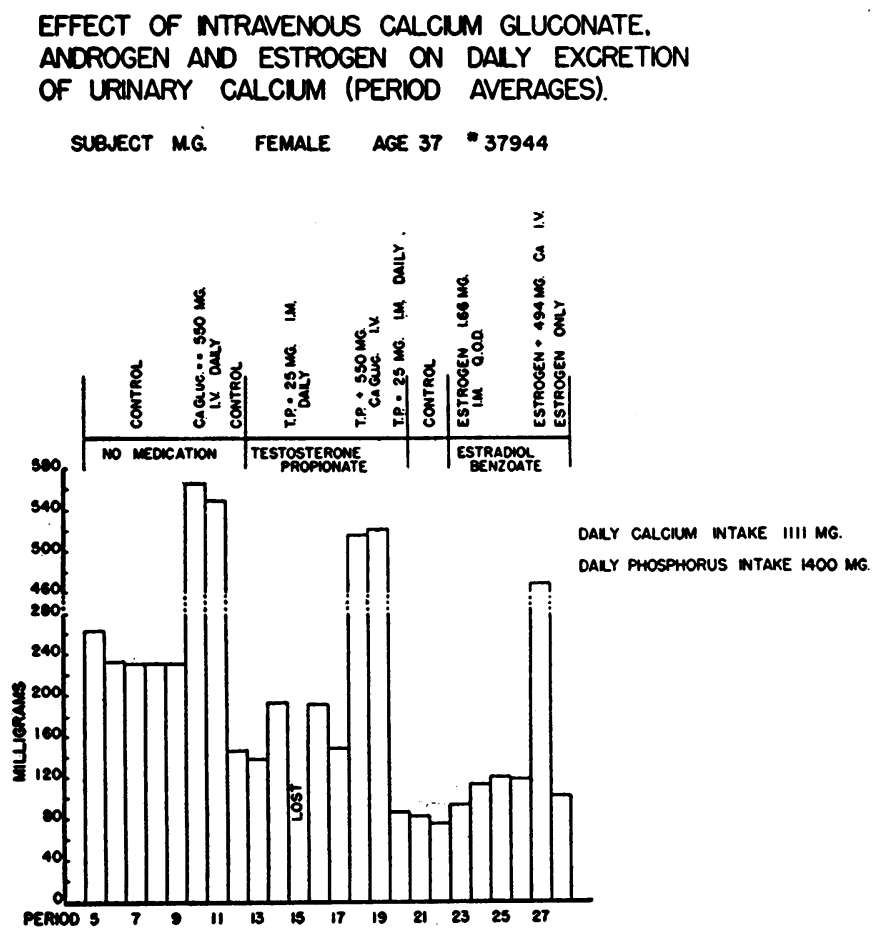

Fig. 1. The Height of Each Column Represents the Average Daily Excretion of Calcium in the Urine per Period of Frve Days

Periods 12 and 13 reveal the decrease in urinary calcium that followed the first series of injections of calcium gluconate. Androgen and calcium gluconate seem to have produced an additive effect in periods 20 through 22 .

tion of calcium in urine, which had resulted from previous medication, had been taken into account there was likewise no indication of an effect of this steroid on retention of parenteral calcium.

C. R., who had osteoporosis, excreted about 75 per cent of the injected calcium during two widely spaced trials. Later, when she was given large oral doses of sodium acid phosphate, the anticipated reduction in urinary calcium occurred (1315). When the ingestion of phosphate was continued through the periods in which supplementary calcium was given intravenously, more of the calcium was retained and the per cent excreted decreased from 75 to 66 . Sufficient retention took place to produce an appreciably positive calcium balance (Table II). It is apparent that saturating this patient with phosphate reduced the excretion of intravenously administered calcium in the urine just as it did calcium derived from food or endogenous sources.

A. H., who had lost a great deal of weight by voluntarily limiting his diet, was in a phase of repletion when the studies were made. He was on a high caloric, high calcium-phosphorus intake and had been in strongly positive nitrogen balance for 16 days prior to the experiment. In spite of this, he was in negative calcium balance and consecutive four-day metabolic periods revealed no evidence of a change in excretion of either urinary or fecal calcium. With the administration of calcium gluconate there was definite retention of calcium ('Table II). The percentage of intravenous calcium escaping in the urine (Figure 2) was lower than in either of the women. There was no decrease in the urinary calcium in the post-injection period. Unfortunately, the observations had to be terminated at this point.

Rate of elimination of intravenous calcium in the urine. Two experiments were performed on the rate at which calcium escaped in the urine. Subject C. R. received calcium gluconate in the usual divided doses on each of four consecutive 


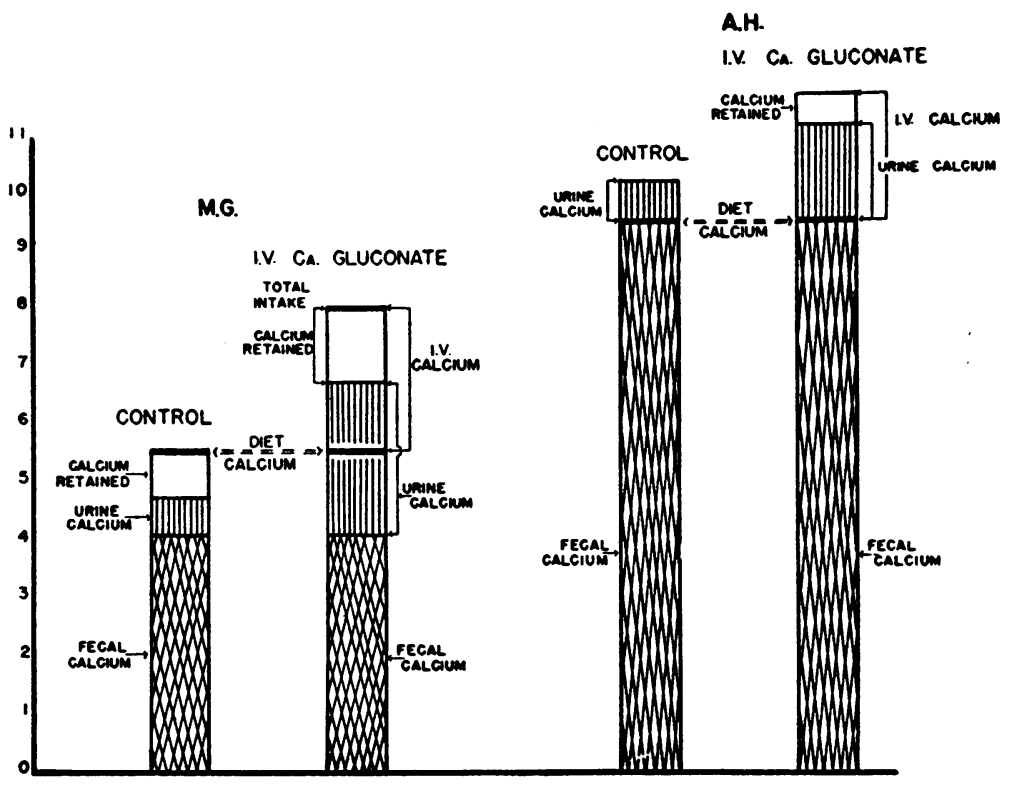

Fig. 2. Effect of an Intravenous Supplement on Calcium Balance

Fecal excretion of calcium appears to be independent of calcium administered intravenously; hence the balance in the experimental period is effected only by the difference between the intravenous dose and the calcium excreted in the urine.

TABLE III

Rate of excretion of calcium in urine after intravenous calcium

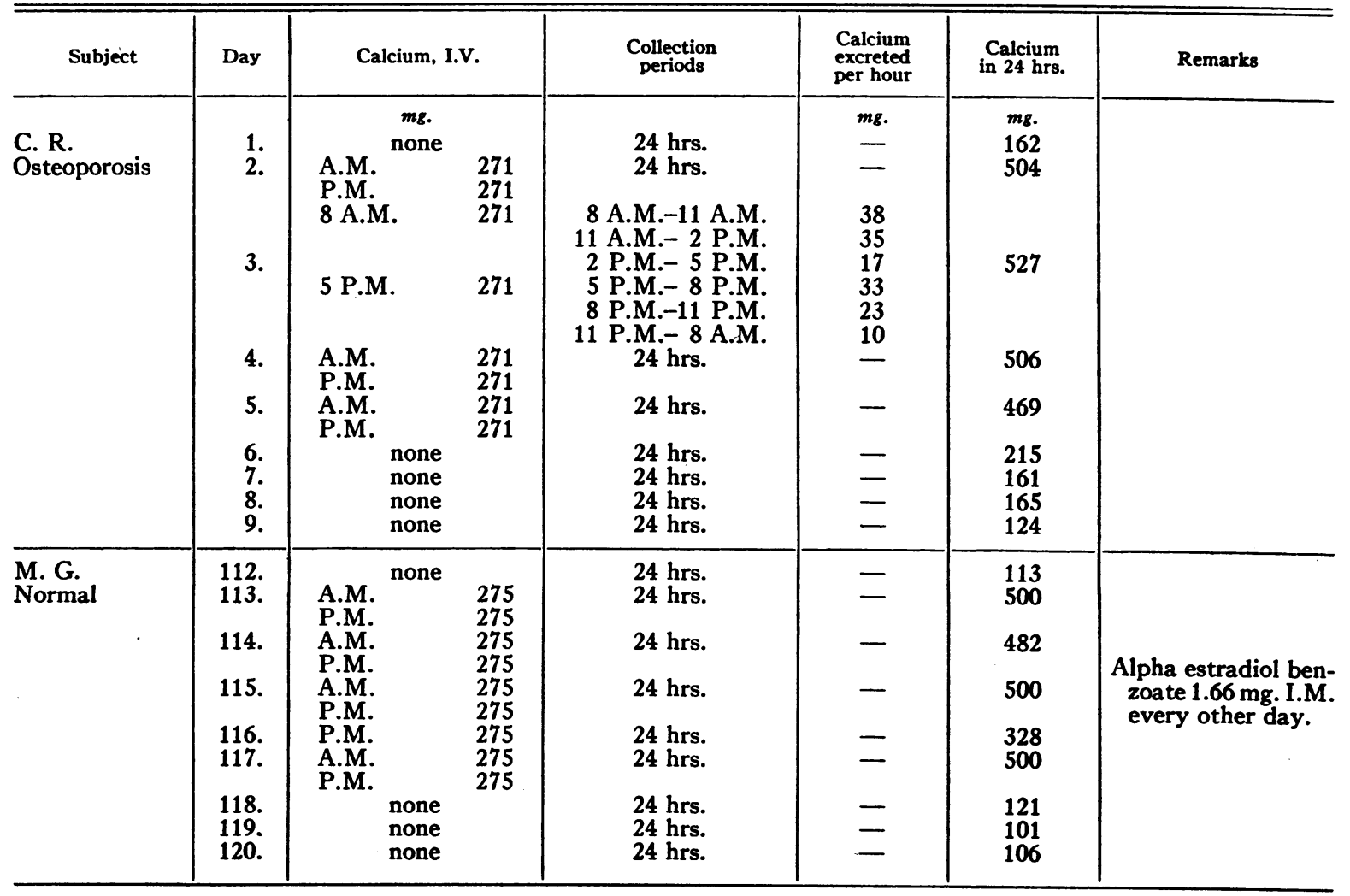


days with the customary prompt rise in urinary $\mathrm{Ca}$, in this case from 162 to $504 \mathrm{mg}$. in 24 hours. (Table III.) On the second day of the period the urine was collected at intervals of three hours from 8:00 a.m. until 11:00 p.m. The maximum rates of excretion occurred in the first three hours after the morning and evening doses and remained high during the second three-hour period. There was some delay in excretion after injections were stopped, as may be noted in the first post-control day. Thereafter, the amount of calcium in urine had fallen to that of the fore-period or below. M. G., on the other hand, did not exhibit any carryover of parenterally administered calcium into the post-control period while under the influence of tions in a completely satisfactory manner. Both tended to be constipated and were somewhat irregular in bowel habits, and it was rarely possible to separate the stools precisely at the carmine markers. For this reason, it has seemed preferable to include the first post-control period following the injection of calcium in order to obtain any calcium which might have been held back because of admixture of experimental and control feces in the colon.

M. G. showed a small increase in fecal calcium during the first periods of calcium administration and a much larger increase when the experiment was repeated during the course of testosterone propionate injections (Table II). The rise in pe-

TABLE IV

Effect of intravenous calcium on urinary phosphorus

(Average Values Expressed as mg./day)

\begin{tabular}{|c|c|c|c|c|c|c|c|c|c|c|c|c|}
\hline \multicolumn{4}{|c|}{ Subject C. R. } & \multicolumn{5}{|c|}{ Subject M. G. } & \multicolumn{4}{|c|}{ Subject A. H. } \\
\hline $\begin{array}{l}\text { Period } \\
6 \text { days }\end{array}$ & $\begin{array}{l}\text { Calcium } \\
\text { I.V. }\end{array}$ & $\begin{array}{l}\text { Calcium } \\
\text { in urine }\end{array}$ & $\begin{array}{c}\text { Phos- } \\
\text { phorus } \\
\text { in urine }\end{array}$ & Day* & $\begin{array}{l}\text { Calcium } \\
\text { I.V. }\end{array}$ & $\begin{array}{l}\text { Calcium } \\
\text { in urine }\end{array}$ & $\begin{array}{c}\text { Phos- } \\
\text { phorus } \\
\text { in urine }\end{array}$ & $\underset{\text { Medica- }}{\text { tion }}$ & $\begin{array}{l}\text { Period } \\
4 \text { days }\end{array}$ & $\begin{array}{l}\text { Calcium } \\
\text { I.V. }\end{array}$ & $\begin{array}{l}\text { Calcium } \\
\text { in urine }\end{array}$ & $\begin{array}{l}\text { Phos- } \\
\text { phorus } \\
\text { in urine }\end{array}$ \\
\hline $\begin{array}{l}4 \\
5 \\
6 \\
7 \\
8\end{array}$ & $\begin{array}{c}\text { mg./day } \\
\mathbf{5 3 8} \\
538 \\
\end{array}$ & \begin{tabular}{|c|} 
mg./day \\
252 \\
231 \\
655 \\
626 \\
195
\end{tabular} & $\begin{array}{c}\text { mg./day } \\
923 \\
936 \\
898 \\
848 \\
963\end{array}$ & $\begin{array}{l}110 \\
111 \\
112 \\
113 \\
114 \\
115 \\
116 \\
117 \\
118 \\
119 \\
120\end{array}$ & $\begin{array}{c}m g . / d a y \\
- \\
\overline{550} \\
550 \\
550 \\
275 \\
550 \\
- \\
-\end{array}$ & $\begin{array}{c}\text { mg./day } \\
122 \\
108 \\
113 \\
500 \\
482 \\
500 \\
328 \\
500 \\
121 \\
101 \\
106\end{array}$ & $\begin{array}{c}\text { mg./day } \\
994 \\
923 \\
1044 \\
795 \\
785 \\
842 \\
758 \\
761 \\
931 \\
946 \\
981\end{array}$ & 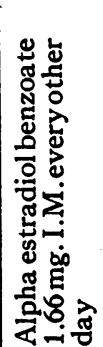 & $\begin{array}{c}8 \\
9 \\
10 \dagger \\
11 \\
12 \\
13 \\
14\end{array}$ & $\begin{array}{c}m g . / d a y \\
- \\
550 \\
550 \\
550 \\
550\end{array}$ & $\begin{array}{c}\text { mg./day } \\
195 \\
185 \\
305 \\
429 \\
433 \\
400 \\
183\end{array}$ & $\begin{array}{c}\text { mg./day } \\
1012 \\
1017 \\
1030 \\
881 \\
895 \\
902 \\
1120\end{array}$ \\
\hline
\end{tabular}

* The excretion of Calcium and Phosphorus was determined daily.

† Injections of Calcium Gluconate on last two days of period only.

estrogen. This may have been because she was in a fairly strongly positive calcium balance at the time.

Fecal excretion of calcium. It is more difficult to determine whether any of the intravenous calcium escaped in the feces. Precise demarcation of feces into periods is often impossible (5), and average values must be depended upon to establish the level of excretion on any particular program. It is certain that the length of time required to obtain a base line will vary from individual to individual. In our experience, to obtain good separation, regular bowel habits are important and the fecal matter should be formed. Neither of our female patients fulfilled the first of these qualifica- riods 10 to 12 is unquestionably well within the limits of error imposed by the difficulties in the separation of the fecal pool. The higher level of fecal calcium in periods 18 to 20 , while the subject was receiving testosterone propionate, is the result of an exceptionally high value for calcium in period 19. On the fourth day of this period, M. G. passed a large loose stool which obviously contained undigested food. It is our opinion that this analysis must be discounted since it is probable that the appearance of undigested food represented vomitus which the patient allowed to become mixed with the feces and failed to report. If the fecal calcium of the first gluconate period (period 18) and that of the first after period (period 20) 
TABLE $V$

Balance dala-subject $M . G$.

\begin{tabular}{|c|c|c|c|c|c|c|c|c|c|c|}
\hline \multirow{2}{*}{$\begin{array}{l}\text { Periods } \\
5 \text { days each }\end{array}$} & \multirow{2}{*}{ Medication } & \multicolumn{3}{|c|}{ Nitrogen } & \multicolumn{3}{|c|}{ Calcium } & \multicolumn{3}{|c|}{ Phosphorus } \\
\hline & & Urine & Stool & Balance & Urine & Stool & Balance & Urine & Stool & Balance \\
\hline $\begin{array}{c}5-9 \\
10-11 \\
12 \\
13,14,16,17\end{array}$ & $\begin{array}{l}\text { Control } \\
\text { Calcium gluconate, I.V. } \\
\text { Control } \\
\text { Testosterone propionate } 25 \mathrm{mg} .\end{array}$ & \begin{tabular}{|l|}
$g m$. \\
53.40 \\
51.41 \\
53.64 \\
36.83
\end{tabular} & $\begin{array}{l}8 m . \\
5.84 \\
5.16 \\
7.91 \\
5.91\end{array}$ & $\begin{aligned} & g m . \\
&+1.43 \\
&+4.10 \\
&-0.88 \\
&+17.68\end{aligned}$ & \begin{tabular}{|l|}
$g m$. \\
1.191 \\
2.789 \\
0.734 \\
0.835
\end{tabular} & $\begin{array}{l}g m . \\
4.200 \\
3.979 \\
5.270 \\
3.973\end{array}$ & $\begin{array}{l}\text { gm. } \\
+0.158 \\
+1.540 \\
-0.449 \\
+0.744\end{array}$ & $\begin{array}{r}8 m . \\
4.640 \\
4.138 \\
4.632 \\
3.512\end{array}$ & \begin{tabular}{|l|}
$g m$. \\
2.200 \\
1.979 \\
2.528 \\
1.957
\end{tabular} & $\begin{array}{l}\text { gm. } \\
+0.161 \\
+0.885 \\
-0.158 \\
+1.533\end{array}$ \\
\hline $18-19$ & $\begin{array}{l}\text { Testosterone propionate and } \\
\text { calcium gluconate }\end{array}$ & 33.84 & 6.85 & +19.98 & 2.593 & \begin{tabular}{|l|} 
\\
\end{tabular} & +0.379 & 3.331 & 2.399 & +1.272 \\
\hline $\begin{array}{c}20 \\
21-22 \\
23-26\end{array}$ & $\begin{array}{l}\text { Testosterone propionate } \\
\text { Control } \\
\text { Alpha estradiol benzoate } \\
1.66 \mathrm{mg} \text {. every other day }\end{array}$ & $\begin{array}{l}37.94 \\
50.88 \\
54.89\end{array}$ & $\begin{array}{l}5.14 \\
5.57 \\
5.84\end{array}$ & $\begin{array}{l}+17.59 \\
+4.22 \\
+0.02\end{array}$ & $\begin{array}{l}0.438 \\
0.398 \\
0.561\end{array}$ & $\begin{array}{l}3.870 \\
4.108 \\
3.949\end{array}$ & $\begin{array}{l}+1.247 \\
+1.050 \\
+1.045\end{array}$ & $\begin{array}{l}3.900 \\
5.190 \\
4.827\end{array}$ & $\begin{array}{l}1.750 \\
1.826 \\
1.919\end{array}$ & $\begin{array}{l}+1.352 \\
+0.491 \\
+0.257\end{array}$ \\
\hline 27 & $\begin{array}{l}\text { Alpha estradiol benzoate, I. M. } \\
\text { and calcium gluconate, I. V. }\end{array}$ & 53.74 & 3.85 & +3.07 & 2.310 & 3.060 & +2.937 & 4.210 & 1.423 & +1.369 \\
\hline 28 & Alpha estradiol benzoate & 55.30 & 5.38 & +0.07 & 0.511 & 3.771 & +1.243 & 4.890 & 1.738 & +0.374 \\
\hline
\end{tabular}

Averages for groups of similar periods.

are averaged, the result, $792 \mathrm{mg}$. per day, is the same as the average of the preliminary control periods on androgen.

The lower fecal calcium of this subject in the final estrogen-calcium gluconate periods may well reflect the decrease in fecal calcium induced by the steroid (12) rather than a specific effect of intravenous calcium. Neither $C . R$. nor A. H. showed any clear-cut evidence of fecal excretion of the parenteral calcium. All subjects were in positive calcium balance during the periods of supplementary calcium administration. The least effect, as was perhaps to be expected, was on C. R., the woman with osteoporosis.
Urinary phosphorus and phosphorus balance. Intravenous injections of calcium were attended by a reduction in urinary phosphorus without increased fecal excretion, which suggests the formation and retention in the body of some compound of calcium and phosphorus, probably bone salt. The effect is demonstrated well in M. G., period 27, when daily determinations of calcium and phosphorus in urine were made (Table IV). Supplementary calcium was responsible for increasing the retention of calcium $740 \mathrm{mg}$., and decreasing the excretion of urinary phosphorus $1,037 \mathrm{mg}$. below that of period 26. As there was no evidence of transfer of $\mathrm{P}$ to the feces or its subsequent ex-

TABLE VI

Balance data-subject $A$. $H$.

\begin{tabular}{|c|c|c|c|c|c|c|c|c|c|c|c|c|}
\hline \multirow{2}{*}{$\begin{array}{c}\text { Periods } \\
4 \text { days } \\
\text { each }\end{array}$} & \multirow{2}{*}{ Medication } & \multicolumn{3}{|c|}{ Nitrogen } & \multicolumn{5}{|c|}{ Calcium } & \multicolumn{3}{|c|}{ Phosphorus } \\
\hline & & Urine & Stool & Balance & Diet & $\begin{array}{c}\text { Supple- } \\
\text { ment }\end{array}$ & Urine & Stool & Balance & Urine & Stool & Balance \\
\hline $\begin{array}{r}7 \\
8 \\
9 \\
10\end{array}$ & $\begin{array}{l}\text { Control } \\
\text { Control } \\
\text { Control } \\
\text { Calcium gluconate } 6 \mathrm{gm} . \\
\text { daily I. V. }\end{array}$ & \begin{tabular}{|c|}
$g m$. \\
41.18 \\
42.25 \\
40.09 \\
38.91
\end{tabular} & $\begin{array}{l}g m . \\
6.75 \\
5.38 \\
8.43 \\
6.24\end{array}$ & $\begin{array}{c}\text { gm. } \\
+14.59 \\
+14.89 \\
+14.00 \\
+17.37\end{array}$ & \begin{tabular}{|c|} 
gm. \\
9.492 \\
9.492 \\
9.492 \\
9.492
\end{tabular} & 1.100 & \begin{tabular}{|c|} 
gm. \\
0.683 \\
0.781 \\
0.739 \\
1.219
\end{tabular} & \begin{tabular}{|c|}
$\mathrm{gm}$. \\
9.520 \\
7.540 \\
11.450 \\
8.735
\end{tabular} & $\begin{array}{c}\text { gm. } \\
-0.711 \\
+1.171 \\
-2.697 \\
+0.638\end{array}$ & $\begin{array}{l}\text { gm. } \\
3.890 \\
4.050 \\
4.070 \\
4.120\end{array}$ & \begin{tabular}{c|}
$\mathrm{sm}$. \\
4.920 \\
3.955 \\
5.720 \\
4.045
\end{tabular} & $\begin{array}{c}\text { gm. } \\
+0.514 \\
+1.319 \\
-0.466 \\
+1.159\end{array}$ \\
\hline 11 & $\begin{array}{l}\text { Calcium gluconate } 6 \mathrm{gm} \text {. } \\
\text { daily I. V. }\end{array}$ & 37.83 & 6.86 & +17.83 & 9.492 & 2.200 & 1.716 & 9.365 & +0.611 & 3.525 & 4.595 & +1.204 \\
\hline 12 & $\begin{array}{l}\text { Calcium gluconate } 6 \mathrm{gm} \text {. } \\
\text { daily I. V. }\end{array}$ & 38.26 & 5.99 & +18.27 & 9.492 & 2.204 & 1.734 & 9.095 & +0.867 & 3.580 & 4.425 & +1.319 \\
\hline 13 & $\begin{array}{l}\text { Calcium gluconate } 6 \mathrm{gm} \text {. } \\
\text { daily I. V. }\end{array}$ & 37.21 & 5.73 & +19.58 & 9.492 & 2.208 & 1.598 & 9.085 & +1.017 & 3.610 & 4.550 & +1.164 \\
\hline 14 & Control & 42.50 & 5.24 & +14.78 & 9.492 & & 0.734 & 8.370 & +0.388 & 4.480 & 4.235 & +0.609 \\
\hline
\end{tabular}

* Given on the last two days only of this period. 
cretion in the post-control period, the reduction in urinary $\mathrm{P}$ must be regarded as an addition of $\mathrm{P}$ to the body. It is clear that the extra amount retained was in excess of that required to combine with calcium retained from calcium gluconate; however it very nearly met the requirement for bone salt if deposited in combination with the total retention of calcium in the period.

Similar changes in urinary phosphorus were demonstrable in the other subjects without especially good correlation between "theoretical" (16) and actual phosphorus balances. In fact, the data for $\mathrm{A}$. H. reveal that even with the increase of $1,180 \mathrm{mg}$. in $\mathrm{P}$ retention induced by calcium injections, an additional $1,500 \mathrm{mg}$. of $\mathrm{P}$ would have been required to combine with the total of the positive $\mathrm{Ca}$ and $\mathrm{N}$ balances of these periods (Periods $10-13$, Table VI). Whether this discrepancy was due to deposition of protein of less than average phosphorus content or to errors inherent in balance experiments is not known.

Effect of 1 . $V$. calcium on urinary nitrogen. In two patients, M. G. and A..H., the injection of calcium gluconate was associated with a decrease in urinary nitrogen. This effect was not very striking in the case of M. G. and might have been discounted had it not occurred regularly each time the calcium gluconate was given (see summary, and Table V). In the case of A. H., however (Table VI) there was a definite reduction in urinary nitrogen.

\section{DISCUSSION}

Tolerance. Mates (17) has injected as much as $182 \mathrm{mg}$. of calcium as the gluconate into patients with a variety of diseases in a matter of 60 to 90 seconds without harmful effects. From the data presented here it is evident that much larger amounts ( $550 \mathrm{mg} . \pm$ ) are well tolerated if given at a slow rate intravenously and in divided daily doses. None of our three subjects experienced any appreciable discomfort or apparent injury over periods of 10 to 12 days and the injections could undoubtedly have been continued much longer.

The wisdom of giving parenteral calcium over extended periods, however, may be questioned, especially in view of the tendency for the metal to be excreted in the urine. In our patients, the amount eliminated in 24 hours was of the order of that observed in moderately severe hyperparathyroidism. The injurious renal effects of the latter disease are too well known to require further comment (18). Apparently similar damage has been produced in the kidneys of animals by the injection of calcium salts (19) and very large amounts of parenteral calcium may give rise to pathological calcification in various tissues (20). The abrupt increase in urinary calcium after intravenous injections suggests that a considerable part of the calcium is excreted before utilization can occur. Possibly much slower rates of injection would avoid flooding the circulation with calcium, the attendant rise in serum calcium and its rapid renal excretion.

Effect on urinary phosphorus. The effect of intravenous calcium on urinary phosphorus is to depress the excretion of the latter (3), just as large oral doses of a soluble phosphate decrease the excretion of calcium in urine (13-15). The resemblance between the action of soluble phosphate on the urinary calcium of patients with hyperparathyroidism $(14,15)$, and on the calciuria of C. R. when she was given phosphate, both during control periods and when she received calcium gluconate intravenously, is clear-cut. A significant reduction in excretion of calcium in the urine occurred in each instance. Temporary decrease in solubility of bone salts when the system is flooded with $\mathrm{PO}^{-}$would seem to be the explanation of this effect. In an acute experiment an excess of $\mathrm{Ca}^{++}$may likewise favor deposition of calcium phosphate in bone and thereby decrease excretion of urinary phosphorus.

Does intravenous calcium decrease the secretion of parathormone? The reason for the decreased excretion of calcium in the urine of the post-injection periods when intravenous calcium was given to M. G., and to a lesser degree in the case of C. R. is mainly a matter for conjecture. Possibly we have the converse of the experiment by Drake, Albright and Castleman (21), who produced parathyroid hyperplasia in rabbits by the injection of a buffered phosphate solution. In the dog, on the other hand, it is claimed that injections of calcium gluconate bring about a reduction in the weight of the parathyroids (22). The mechanism of the post-calcium gluconate depression of excretion of calcium in the urine of M. G. would then be explainable as a temporary decrease in the secretion of parathormone.

Effect on nitrogen. In the two subjects in 
which increased retention of nitrogen appeared to be associated with the calcium gluconate injections, it is important to know whether the extra retention of $\mathrm{N}$ represented merely an accumulation of nonprotein nitrogen in the body water or whether it actually was retained as protein. The evidence in A. H., who showed the greater effect, is that it was retained as protein, for the serum N.P.N. did not increase during the experiment, and gain in weight was only $2.1 \mathrm{Kg}$. which could account for retention of but $0.69 \mathrm{gm}$. of $\mathrm{N}$ as N.P.N., while the observed increase in nitrogen retention was $15.16 \mathrm{gm}$.

It does not seem probable that $\mathrm{N}$ retention was the result of a nitrogen-sparing effect of the extra calories derived from gluconic acid since the amount of the latter injected was not more than $5.5 \mathrm{gm}$. a day. Either the increased retention of $\mathrm{N}$ in these two patients is purely a matter of coincidence or intravenous calcium gluconate stimulates some mechanism which requires $\mathrm{N}$ retention, such as the formation of new osteoid tissue.

\section{SUM MARY}

1. Intravenously administered calcium gluconate $(550 \mathrm{mg}$. Ca daily) was used to supplement the dietary intakes of three human subjects. These included an essentially normal woman, a woman with postmenopausal osteoporosis, and a man who was recovering from a period of partial starvation.

2. A considerable part of the calcium was excreted in the urine within 24 hours.

3. No consistent effect on fecal calcium could be demonstrated.

4. Some of the calcium was retained in each case. If one considers the urinary calcium alone, the retention was greatest in the male subject during repletion and least in the woman with osteoporosis.

5. Intravenous calcium was followed by a decrease in urinary calcium excretion in both female patients. It is suggested that this may have been caused by depression of the activity of the parathyroid glands.

6. Calcium decreased the excretion of phosphorus in the urine of all patients without increasing its fecal excretion. This effect is the converse of that observed when large doses of a soluble phosphate are given orally.
7. In the normal woman, steroid therapy (testosterone propionate and alpha estradiol benzoate) increased the retention of both the $\mathrm{Ca}$ and $\mathrm{P}$ absorbed from the food, but did not seem to increase the retention of the calcium supplement.

8. A small nitrogen-sparing effect was noted in the male subject and in the normal woman during periods when calcium gluconate was injected.

\section{BIBLIOGRAPHY}

1. Greville, G., Study of the blood-calcium following intravenous injection of calcium salts. Biochem. J., 1931, 25, 1931.

2. Grosser, P., Stoff wechseluntersuchungen an Rachitikern. Ztschr. f. Kinderh., 1920, 25, 131.

3. Albright, F., and Sulkowitch, H. W., The effect of vitamin $\mathrm{D}$ on calcium and phosphorus metabolism; studies on four patients. J. Clin. Invest., 1938, 17, 305.

4. McCance, R. A., and Widdowson, E. M., Fate of calcium and magnesium after intravenous administration to normal persons. Biochem. J., 1939, 33, 523.

5. Duncan, L. E., Jr., Mirick, G. S., and Howard, J. E., Total intravenous alimentation; its effect on mineral and bacterial content of feces. Bull. Johns Hopkins Hosp., 1948, 82, 515.

6. Armstrong, W. D., and Lienke, R., Personal communication.

7. Nicolaysen, R., Untersuchungen über die Kalkausscheidung bei Hunden. Ein Beitrag zur Physiologie des Kolans. Skandinav. Arch. f. Physiol., 1934, 69, Supp. 1.

8. Washburn, M. L., and Shear, M. J., Composition of bone. XIII. Direct gravimetric determination of $\mathrm{Ca}, \mathrm{Mg}$ and PO. J. Biol. Chem., 1932, 99, 21.

9. Kochakian, C. D., and Fox, R. P., Microdetermination of calcium by titration of the oxalate with ammonium hexanitratocerate. Indust. \& Engin. Chem. (Analyt. Ed.), 1944, 16, 762.

10. Fiske, C. H., and Subbarow, Y. The colorimetric determination of phosphorus. J. Biol. Chem., 1925, 66, 375 .

11. Albright, F., Cushing's syndrome; its pathological physiology, its relationship to adrenogenital syndrome, and its connection with the problem of reaction of the body to injurious agents ("alarm reaction" of Selye). Harvey Lectures, 1942-43, 38, 123.

12. Reifenstein, E. C., Jr., and Albright, F., The metabolic effects of steroid hormones in osteoporosis. J. Clin. Invest., 1947, 26, 24.

13. Farquharson, R. F., Salter, W. T., and Aub, J. C., Studies of calcium and phosphorus metabolism. XIII. The effect of ingestion of phosphates on the excretion of calcium. J. Clin. Invest., 1931, 10, 251.

14. Albright, F., Bauer, W., Claflin, D., and Cockrili, J. R., Studies in parathyroid physiology. III. The 
effect of phosphate ingestion on clinical hyperparathyroidism. J. Clin. Invest., 1932, 11, 411.

15. Bassett, S. H., Mineral exchanges of man. V. Balances of electrolytes in a case of hyperparathyroidism. J. Nutrition, 1935, 9, 323.

16. Reifenstein, E. C., Jr., Albright, F., and Wells, S. L., The accumulation, interpretation and presentation of data pertaining to metabolic balances, notably those of calcium, phosphorus, and nitrogen. J. Clin. Endocrinol., 1945, 5, 367.

17. Mates, J., Ein versuch der praktischen Verwertung der Kalziumkurven nach intravenosen Injektionen von "Calcium-Sandoz." Praxis, 1943, 32, 571.

18. Albright, F., Baird, P. C., Cope, O., and Bloomberg, E., Studies on the physiology of the parathyroid glands. IV. Renal complications of hyperparathyroidism. Am. J. Med. Sc., 1934, 187, 49.
19. Christiansen, H., Investigation into the excretion of calcium. Doctorate thesis, Univ. Copenhagen, 1936, 108 pages. Abstracted in Nutrition Abstr. \& Rev., 1937, 6, 722.

20. Katase, A., Experimentelle Verkalkung am gesunden Tiere. Beitr. z. Path. Anat. u. z. allg. Path., 1914, 57, 516.

21. Drake, T. G., Albright, F., and Castleman, B., Parathyroid hyperplasia in rabbits produced by parenteral phosphate administration. J. Clin. Invest., 1937, 16, 203.

22. Pierre, M., de Boissezon, P., and Lombard, C., Variations pondérales des parathyroides externes du lapin et du chien sous l'influence d'injections parentérales répétées de phosphate de sodium et du gluconate de calcium. Compt. rend. Soc. de biol., 1939, 130, 341. 